Chicago-Kent College of Law

Scholarly Commons @ IIT Chicago-Kent College of Law

4-24-2006

\title{
Patents on Human Genes: An Analysis of Scope and Claims
}

Lori B. Andrews

IIT Chicago-Kent College of Law, landrews@kentlaw.iit.edu

Jordan K. Paradise

Seton Hall University - School of Law, paradijo@shu.edu

Timothy R. Holbrooke

Emory University School of Law, tholbrook@emory.edu

Follow this and additional works at: https://scholarship.kentlaw.iit.edu/fac_schol

Part of the Intellectual Property Law Commons, and the Science and Technology Law Commons

\section{Recommended Citation}

Lori B. Andrews, Jordan K. Paradise \& Timothy R. Holbrooke, Patents on Human Genes: An Analysis of Scope and Claims, 307 Science 1566 (2006).

Available at: https://scholarship.kentlaw.iit.edu/fac_schol/727

This Article is brought to you for free and open access by the Faculty Scholarship at Scholarly Commons @ IIT Chicago-Kent College of Law. It has been accepted for inclusion in All Faculty Scholarship by an authorized administrator of Scholarly Commons @ IIT Chicago-Kent College of Law. For more information, please contact jwenger@kentlaw.iit.edu, ebarney@kentlaw.iit.edu. 
tors are expected to consult in order to investigate whether something has been

\title{
Patents on Human Genes:
}

\section{An Analysis of Scope and Claims}

\author{
Jordan Paradise, *Lori Andrews, Timothy Holbrook
}

P atents by their very nature limit what others can do, offering a period of exclusive rights over the invention to the patent holder in return for public disclosure of information about the patented invention so that other inventors can build on itfor example, by making a better mousetrap out of other materials. In the case of a human gene sequence, however, the "invention" is the information. Consequently, disclosure of that information does not allow others to build on it. Gene patents, especially, limit what can be done in the realm of scientific research and medical care because there are no alternatives to a patented gene in diagnosis, treatment, and research (1-4). When gene patents are granted improperly and in an overly broad manner, those problems are compounded.

U.S. patent law requires that subject matter be useful (5), novel (6), and nonobvious (7) and fulfill four basic disclosure requirements: written description, enablement, best mode, and definiteness ( 8 ). When a patent is issued, the patent holder gains the right to exclude others from making, using, selling, offering to sell, or importing the invention for 20 years (9).

\section{Evaluating Gene Patent Claims}

To gain an understanding of whether the claims contained within issued patents covering human genetic material meet the existing statutory requirements under U.S. patent law (10), we undertook a multiyear project overseen by an advisory board that included two geneticists, two consumer advocates, and the head of an organization that runs a nonprofit tissue bank.

Eleven project personnel (including lawyers, licensed members of the Patent Bar, law students, and molecular biologists) identified human gene patents that represented a range of genetic diseases-from single gene to multigene disorders, from diseases where the genetic predisposition

The authors are with the Illinois Institute of Technology, Chicago-Kent College of Law, 565 W. Adams, Chicago, IL 60661, USA.

*Author for correspondence. E-mail: jparadise@kentlaw.edu has been identified to those where the causal nexuses are still being identified. We used the term "human gene patent" to include not only patents on complete human gene sequences, but patents that cover any human genetic material, such as mutations in a gene, or diagnostic methods that utilize human genetic material that would effec-

patented or there is an application pending. The patents that we analyzed are not an exhaustive list of human gene patents issued by the USPTO during this period, owing to the rolling time frame and our specific search terms.

For our analysis, we examined 74 relevant patents on human genetic material, all of which contained multiple claims (such as a claim over a gene or a claim over mutations of that gene). Because the USPTO and the courts examine each claim with respect to its validity, we did so as well, assessing the 1167 claims in the 74 patents. Where the project personnel felt that a specific claim did not meet one or more of the legal requirements of patentability, it was deemed problematic. These findings are the conclusions of project personnel and are not necessarily predictive of eventual validity determinations by the courts or the USPTO.

We found that $38 \%$ of claims were problematic (see table on

tively preclude the use of that material by others. We chose genetic diseases that were subject to public attention and for which problems in gene patents could potentially have an impact on research and health care. The human gene patents were not chosen with any expectation that they would have problems with their claims.

The analysis was done in a rolling fashion over the period of January 2003 to May 2004, to generate a database of at least 1000 individual claims. Initially, we examined human gene patents that dealt with the main gene or genes associated with two multigenic diseases: Alzheimer's disease and breast cancer. We then examined four single-gene diseases: ataxia telangiectasia, Canavan disease, familial dysautonomia, and hereditary hemochromatosis. We then chose three diseases that were multigenic in nature and whose genetic basis was less clear, for which a number of genes have been identified as playing a key role: asthma, obesity, and schizophrenia.

A list of human gene patents for the nine selected genetic diseases was generated by means of the U.S. Patent \& Trademark Office (USPTO) database, advance search option (11). We used the USPTO Web site because it is the publicly accessible, federal government site that scientists and inven- page 1567 ). Some claims had multiple problems, resulting in 677 cumulative problems within the 448 problematic claims. Of the 677 total problems identified, written description and enablement/utility problems were the most frequent (see figure page 1567). Many patents claimed far more than what the inventor actually discovered. Some applicants took advantage of the redundancy of the genetic code by, for example, claiming the sequence of a protein within a patent and then also asserting rights over all of the DNA sequences that encode for that protein without describing those DNA sequences.

Some patents exhibited written description problems by claiming discoveries the patent holder did not specifically describe. One patent covers not only the particular polymorphism the inventor discovered but all other polymorphisms discovered in the future by anyone else in a region encompassing over 12 mega-base pairs (Mbp).

Other patent claims were problematic with respect to utility. In one patent, the inventor had shown how a polymorphism could be used to predict asthma. The inventor additionally claimed various uses of the polymorphism to predict other conditions, although the inventor did not show that the polymorphism was linked to those conditions. 
Another troubling issue arose where a claim was drafted disclosing only a correlation between two things, often the presence of an isoform or mutation and some multigenic disorder or a disorder having a genetic component. In some cases, the patent holder did not describe how the correlation was used to predict the disease. One such patent claims a method of detecting whether a subject is at increased risk of developing late-onset Alzheimer's disease, comprising directly or indirectly detecting the presence or absence of a particular protein isoform. The claim does not account for other factors that relate to a person's developing Alzheimer's disease and does not indicate the specific relation between the presence of the isoform and the increased risk, but merely provides that there is a correlation. In fact, even where a patient does not have the isoform, he or she could still develop the disease, and those with the isoform might never develop the disease. The "indirect" detection method is also vague enough that it could include any diagnosis based on external factors as well, such as memory loss (a diagnostic method that was not invented by the patent applicant).

We also found patent claims that suffered from one or more problems but were saved from being classified as problematic by the drafting language. For example, one claim reads, "( $t$ )he method of claim 1,2 , or 3 , wherein the method further comprises amplifying the sequence-altered PAH DNA by use of the polymerase chain reaction (PCR)." Two of the three referenced claims were problematic. Claim 1 had written description, enablement/utility, and novelty/nonobviousness problems and claim 3 had enablement/utility problems. Project personnel concluded that this claim was not problematic, however, because it referenced claim 2 , which contained no problems with any of the

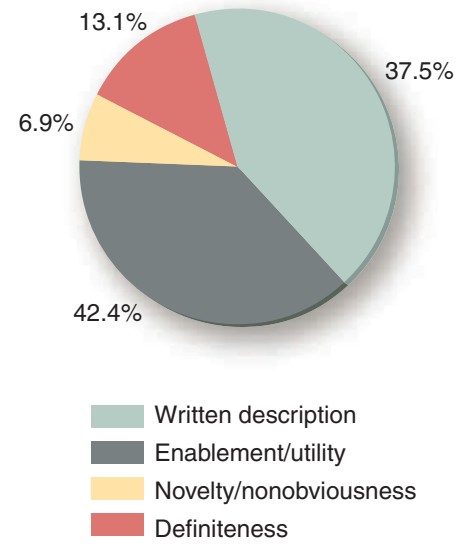

Analysis of problems observed within claims.
74 1167

Total claims with problems

Cumulative problems 448 667

ning patents on genes entirely or narrowing their scope, exempting researchers and diagnosticians from the reach of the patents, creating a system of either patent pools or compulsory licensing, recognizing the rights of third parties to oppose the granting of a particular gene patent, and allowing the people who are the sources of the patented genes to have a greater say in their use (4).

Another avenue may be to have the USPTO remedy internal problems that lead to the issuance of gene patents that arguably do not comply with existing patent law. This is not a new problem or one that is specific to gene patents $(14,15)$. As with any new technology, the USPTO must have competent patent examiners to guarantee that patents are not issued that are overly broad or overarching. For example, examiners in the newly created business method patent category were criticized in the late 1990s for granting poor-quality, overbroad patents lacking novelty, all of which are problems attributed to improper technical backgrounds, inadequate training, and financial incentives. Because some examiners within the patent office may not be familiar with DNA-based technologies, one potential remedy may be more training or special selection of patent examiners from a related educational background (14).

Some have even argued that applications should be reviewed by established categories. This language may create a chilling effect on researchers who want to use methods listed in claims 1 and 3 of the patent, but do not realize that the patent is open to challenge as not validly covering those methods.

\section{Discussion}

Prior studies have found that gene patents have the potential to deter medical research and health care $(12,13)$. A variety of policy alternatives are being considered to remedy these negative effects. These include ban-

the USPTO with different levels of scrutiny, depending on how much social cost they entail (14). Reports indicate that on average, the total time spent by a patent examiner on a patent application is about 18 hours (16). With gene patent applications often involving extensive biological sequence information for each individual claim, it may be that adequate time is not being invested in thoroughly investigating the patentability of the claimed material. Where the enforcement of a patent has the potential to be so costly to society in terms
Total patents

of medical research, health care, and downstream innovation because there are no adequate substitutes, safeguards could be installed to ensure that the application is examined more closely (14).

The USPTO could also revamp financial incentives to promote decisions based on the quality of patents rather than their quantity. Currently, patent examiners are encouraged with monetary bonuses to grant patent applications, a policy that has the unsettling effect of rewarding examiners for quickly pushing patents through the patent office. Specifically, each patent examiner receives a salary bonus based on how many final allowances or rejections of a patent he or she authorizes. Because a rejection can be challenged and may not become final for quite some time, it is easier to receive a bonus by allowing patents (14). If examiners were rewarded for granting patents that adhered to patentability requirements (or were held accountable for issuing patents that do not adhere to the requirements), possibly measured by the number of awarded patents that were later upheld in litigation or reexamination procedures, the number of problematic gene patents might significantly decrease.

Whether through amendments to the patent law, alternative licensing mechanisms, or policy changes in the USPTO itself, something needs to be done about the number of human gene patents being granted that arguably do not measure up to the federal patent law.

\section{References and Notes:}

1. See M. K. Cho, in Preparing for the Millennium: Laboratory Medicine in the 21st Century (AACC Press, Orlando, FL, ed. 2, 1998), pp. 47-58.

2. J. F. Merz, A. G. Kriss, D. G. Leonard, M. K. Cho, Nature 415, 577 (2002).

3. E. G. Campbell et al., JAMA 287, 473 (2002).

4. See L. B. Andrews, Nature Rev. Genet. 3, 803 (2002).

5. 35 U.S. Code (USC) §101.

6. 35 USC $\$ 102$.

7. 35 USC $\$ 103$

8. 35 USC $\S 112$

9. 35 USC $\S 154$

10. Specific information regarding the patents analyzed is available from the authors upon request.

11. http://patft.uspto.gov/netahtml/search-adv.htm

12. K. Blanton, Boston Globe, 24 February 2002, p. 10.

13. S. Gad et al., J. Med. Gen. 38, 388 (2001).

14. See R. P. Merges, Berkeley Tech. Law J. 14, 577 (1999).

15. J. H. Barton, Science 287, 1933 (2000).

16. M. A. Lemley, Northwestern Univ. Law Rev. 95, 1495 (2001).
17. Supported by grant DE-FG02-02ER63460 from the Office of Biological and Environmental Research, the Office of Science, U.S. Department of Energy (DOE); and The Robert Wood Johnson Foundation Investigator Awards in Health Policy Research Program. We thank the following research assistants for their dedicated work analyzing the patents: $\mathrm{M}$. Bauer, T. Ebersole, C. Mitchell, G. Prihar, M. Timm, A. Rooke, and G. M. Zinkl. We are also grateful to $L$. Rosenow for her role as an investigator in the DOE grant and to C. G. Janson who acted as an advisor to the project.

Supporting Online Material

www.sciencemag.org/cgi/content/full/307/5715/1567/DC1

10.1126/science 1105162 